\title{
Value relevance of deferred tax assets in the Brazilian banking industry ${ }^{\star}$
}

\section{Leandro Dias Guia ${ }^{1}$}

(D) https://orcid.org/0000-0003-2988-6776

Email: leandrodias1@yahoo.com.br

\author{
José Alves Dantas ${ }^{1}$ \\ (D) https://orcid.org/0000-0002-0577-7340 \\ Email: josealvesdantas@unb.br
}

\begin{abstract}
1 Universidade de Brasília, Faculdade de Economia, Administração, Contabilidade e Gestão Pública, Departamento de Ciências Contábeis e
\end{abstract} Atuariais, Brasília, DF, Brazil

Received on 04.27.2018 - Desk acceptance on 06.13.2018 - $3^{\text {rd }}$ version approved on 12.03.2018 - Ahead of print on 04.25.2019

Associate Editor: Eliseu Martins

\begin{abstract}
This study aimed to investigate the informational relevance to the capital market of the significant level of deferred tax assets (DTAs) in the Brazilian banking industry, identifying whether such assets influence the market value of publicly-held banks. The value relevance of DTAs in the banking industry is an incipient topic in the national literature, with conflicting results in the international research. Brazil presents characteristics, most notably regarding the dimension of the asymmetries between accounting and taxable profit, which justify concern about the effects of DTAs on the market value of banks. The literature highlights issues involving DTAs related to their ability to generate economic benefits and control of the entity, especially in the banking industry, due to not fulfilling the role of financial intermediation, which would make them devoid of economic substance. This would signal potential bank risks and weaknesses, such as a reduction in the quality of equity and profits, in addition to distortions in the economic-financial indicators, which would justify a negative perception on the part of investors. As the study's main contribution to the literature, we can highlight the identification that in the Brazilian market, the asymmetries between banks' taxable and corporate earnings, the origin of deferred tax assets, weigh negatively on the market value of these institutions. We empirically tested the hypothesis in the Brazilian capital market, using data from 2000 to 2017 on publicly-held banks, by estimating two models - Market-to-Book and Ohlson (1995). The results of this study show that in the Brazilian capital market there is a negative relationship between the volume of the banks' DTAs and the market value of these entities, corroborating the hypothesis that investors identify the relevance of these assets in the equity structure as a sign of the quality of the equity and the profit of these entities being undermined.
\end{abstract}

Keywords: value relevance, banks, market value, deferred tax assets (DTAs).

Correspondence address

Leandro Dias Guia

Universidade de Brasília, Faculdade de Economia, Administração, Contabilidade e Gestão Pública,

Departamento de Ciências Contábeis e Atuariais,

Campus Universitário Darcy Ribeiro, Bloco A-2, $1^{\circ}$ andar

CEP 70910-900 Asa Norte - Brasília - DF - Brazil

* Article presented at the XVII USP International Conference in Accounting, São Paulo, SP, Brazil, July 2017. 


\section{INTRODUCTION}

This study investigates the informational relevance for the capital market of the expressive level of deferred tax assets (DTAs) in the Brazilian banking industry, the controversies involving these balance sheet items, and the potential implications for the banking entities. At the center of the discussions is a peculiar type of asset, questioned with regard to their capacity to generate economic benefits and control of the entity in favor of accruals-based accounting (Ayers, 1998; Black, 1966; Brown, Collins \& Thornton, 1993; Kam, 1990; Revsine, 1969; Skinner, 2008; Wolk, Dodd \& Rozycki, 2008). DTAs originate from the asymmetry between the accounting and tax criteria for measuring income and exist as a representation of a particular economic benefit to be realized in the future, in the form of a tax deduction.

These asymmetries are generally characterized by the accounting recognition of non-deductible expenses for tax purposes, but they can, in the future or under certain conditions, become deductible. Thus, DTAs are a type of economic benefit and will be consumed when the originating expenses become deductible for tax purposes. The realization of these assets will occur when, in the period allowed, they can reduce the amount on which taxable income is calculated, giving rise to the benefit recognized as an asset (Brown et al. 1993; Kam, 1990; Nurnberg, 1971; Shield, 1957; Wolk et al., 2008). In addition, DTAs can also arise from tax losses, since there is a legal provision allowing for them to be offset in future taxable income.

In the banking industry, given the characteristics of financial intermediation assets, this issue is particularly controversial. This controversy is reflected in the global demands to maintain minimum standards for banks' own equity, the rules for which require the exclusion of DTAs when calculating regulatory capital due to the low quality attributed to these assets for the resilience needed by the global banking system, as stipulated by the Basel Committee on Banking Supervision (BCBS, 2011).

If in economic environments in which asymmetry between accounting and tax criteria is not so relevant, DTAs may not even significantly affect the equity structure of banking entities, in jurisdictions with strong discrepancies between these criteria, such as in the Brazilian case, the volume of these assets can represent a substantial portion of bank equity. The data in Figure 1 , limited to publicly-held banks, confirm the evolution of the stock of DTAs for this set of banks since 2007 and their representativeness - they correspond to $44 \%$ of the net equity (NE) of these entities.

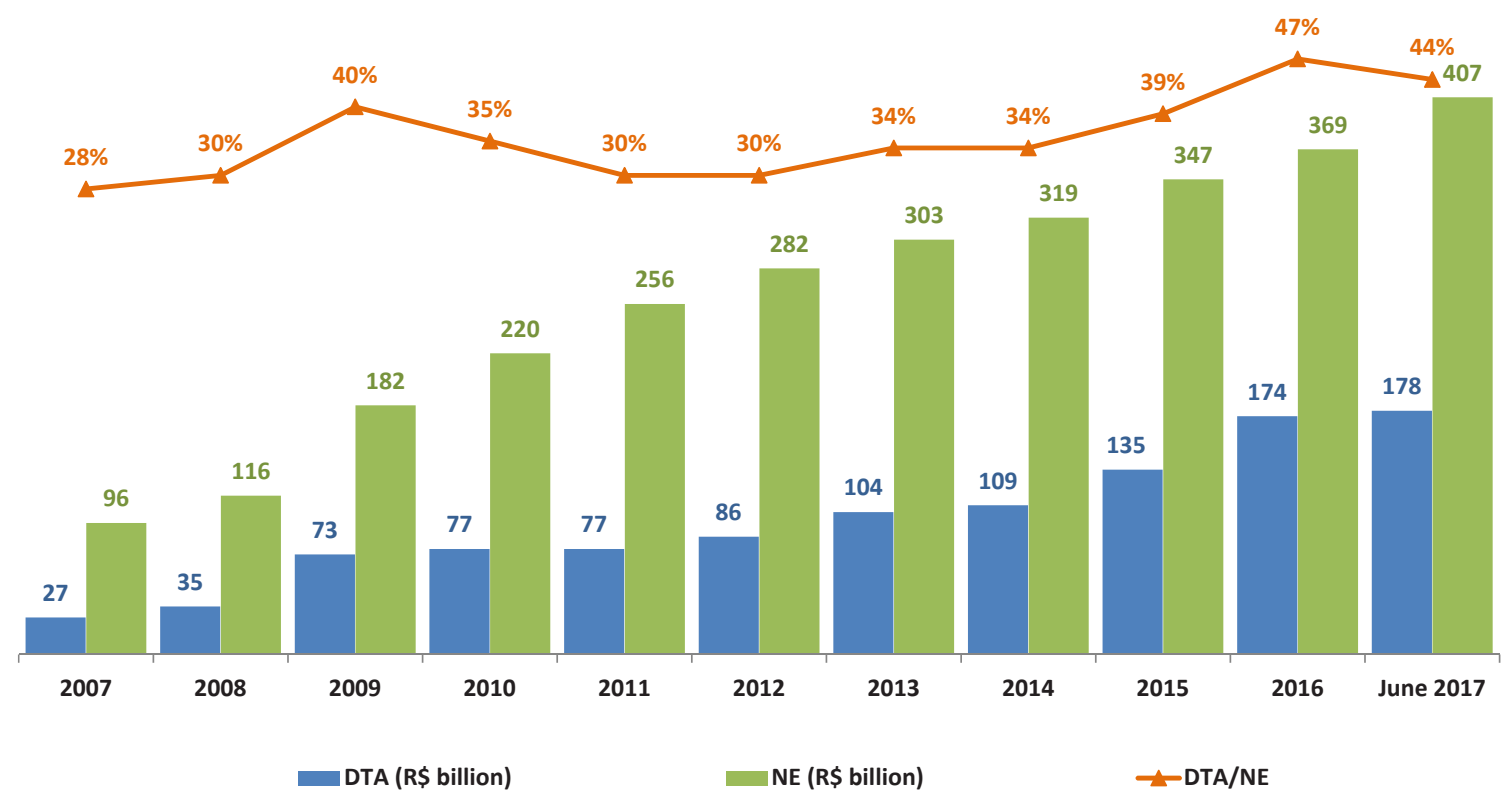

Figure 1 Evolution of deferred tax assets (DTAs) in publicly-held Brazilian banks $N E=$ net equity.

Source: Elaborated by the authors. 
This type of discussion is coherent with the concern expressed by Skinner (2008), for whom the phenomenon of the increasing relevance of DTAs, which are strange to the characteristics of the activity of financial intermediation, may be interpreted as causing a series of distortions in the financial statements of banks, notably in relation to the quality of capital indicators when examining the 2008 banking crisis in Japan.

The concern in relation to the issue is also justified by the relevance of these assets revealing severe sterilization in bank assets, as they are devoid of economic substance (they are not monetized), which may contribute to an increase in the cost of credit. The concern is not concentrated in the condition for accounting recognition, but in the consequences that this causes in the equity structure and performance indicators of banks, with effects in the way users evaluate the information relating to DTAs. In addition, they depend on future taxable income to generate economic benefit, a situation that is aggravated by the absence of an adjustment to present value - DTAs measured by their nominal values do not represent future net economic benefits discounted by a risk rate, which in an evaluation of the entity's value increases the volatility of the pricing of its assets and, consequently, increases investors' perceptions of risk, especially in future cash flows over a long term horizon (up to 10 years) - and due to assetization based on highly subjective assumptions (Moody's Corporation, 2015; Standard \& Poor's Ratings Services, 2016).

Consequences of this phenomenon can indicate the weakening of NE (in the absence of future taxable income DTAs will be recorded as losses), a decrease in earnings quality, a reduction in regulatory capital, as well as causing distortions in banks' economic-financial indicators, particularly those related to the quality of the institutions' capital (Badenhorst \& Ferreira, 2016; BCBS, 2011; Graul \& Lemke, 1976; Skinner, 2008).

Although each one of these characteristics is not exclusive to DTAs, a combination of all of these elements is not common in one specific balance sheet item. Moreover, in the Brazilian banking industry, all these negative effects are enhanced by the heightened relevance of DTAs, which correspond to around $44 \%$ of the NE of publicly-held Brazilian banks (Figure 1).

By interpreting this phenomenon as a reduction in the quality of earnings, NE, and assets, and an increase in the risks to which banks are exposed, it is natural to suppose that investors will react negatively to the dimension of the DTA stock in the equity structure composition, revealing a negative effect on market value. This is particularly relevant if we consider that these assets, which represents almost half of the banks' NE, are not monetized, as well as them not being the object of an adjustment to present value (suggesting a relevant risk of asset overestimation), which would reinforce investors' expectations of a negative reaction.

From an opposite, but understandable perspective, investors' can interpret this fact as a significant volume of expenses paid in advance by the banks and which will flow in future economic benefits, attributing a positive value to DTAs, as identified by Ayers (1998), in the United States of America, and by Badenhorst and Ferreira (2016), in Australia and in the United Kingdom. This would also be coherent with the perception of earnings persistence, the sensation of maximizing the current value of the entities (current partners or owners do not support the effect of a reduction in capital with expenses attributable to future periods), and supposed prevention of an undue transfer of wealth among partners in different reporting periods, among others, as argued by Watts and Zimmerman (1986) and Cao and Narayanamoorthy (2006).

Considering the above, this study aimed to investigate the informational relevance of DTAs in the Brazilian banking industry, by identifying whether these assets influence the market value of the publicly-held banking institutions. It seeks to evaluate the predictive value of this information for investors, contributing to an advancement of the literature regarding the relevance and usefulness of accounting information for the capital market, specifically investigating the banking industry, in which the stock of DTAs will be evaluated.

To achieve this objective, two regression models were estimated - Market-to-Book (MTB) and Ohlson (1995) - using data from 2000 to 2017 on 38 publiclyheld banks listed on the Brasil, Bolsa, Balcão (B3 S.A.) stock exchange in the period, in order to test whether there is a significant relationship between share value and DTA stock. The results reveal that, in the Brazilian capital market, there is a negative association between the magnitude of DTAs and the market value of banks, contributing to the still scarcely explored literature with regard to the implications of deferred taxes in banks and in the Brazilian capital market. 


\section{THEORETICAL FRAMEWORK AND LITERATURE REVIEW}

From a theoretical perspective, DTAs are considered to be a unique type of asset that are questionable with regard to generating wealth and control of the entity, existing in favor of accruals-based accounting as a necessary representation of future economic benefits (Black, 1966; Carey, 1944; Revsine, 1969). These future economic benefits will be realized when the originating expenses become deductible for tax purposes (Brown et al., 1993; Wolk et al., 2008).

The informational role of DTAs may be an important source of analysis of the divergences between corporate accounting and the tax system. While accounting aims to capture the economic relevance of events, the system of tax rules is a process with an economic bias in the interest of the State, in which legislators seek to raise more funds, stimulate or inhibit a particular sector or activity, etc. Despite these asymmetries, they should be aligned to some extent (Hanlon \& Heitzman, 2010).

In relation to this, Schultz and Johnson (1998) conducted a comprehensive study from the theoretical perspective of the most frequently debated controversies regarding the accounting treatment of income, since the first standards issued for the Generally Accepted Accounting Principles (U.S. GAAP), in the 1930s, up to the 1990s. These discussions primarily addressed the partial, total, or non-recognition of deferred tax assets and liabilities (DTLs) and the absence of a present value adjustment when measuring these items. According to the authors, the various approaches to the different criteria for recognizing and measuring taxes on earnings have been addressed by regulators, accounting professionals, and the academic community, but no group has dominated the debate from a historical perspective, as the issue is so controversial.

Probably due to the great variety of accounting alternatives for recognition and measurement and discrepancies between theoretical coherence (conceptual structure) and procedures of a practical nature, no consensus has been reached regarding the issue. Wolk et al. (2008) summarize this context when affirming that the allocation of taxes on earnings is one of the most controversial issues that have arisen in accounting theory and has historically caused heated debates.

\subsection{Arguments in Favor and Against Recognizing DTAs}

From the perspective in favor of recognizing DTAs, the arguments raised are that taxes on earnings should be considered as business expenses and, as such, should be subject to the concept of offsetting and accruals-based accounting. Although they are not directly related to revenue, tax on earnings expenses should be recorded in the period in which they have occurred and not when they are paid. If this does not happen, the accruals-based accounting would be violated (Kam, 1990). Along this same line of understanding, Wolk et al. (2008) understand that tax on earnings expenses should be allocated, when necessary and practical, as DTAs, so that the income statement for the financial period reflects the expenses attributable to particular earnings.

Another argument in favor is that if the tax on earnings were not deferred, the amount of the expense would be subject to wide variability, making earnings fluctuate. Thus, earnings would not be the best representation of the entity's performance in relation to its operations, since they would be influenced by the cash flow of the tax value (Wolk et al., 2008). In addition, according to Shield (1957) and Kam (1990), if deferment were not allowed, the users of financial statements would be induced to error, primarily with respect to the entity's future cash flows, since there would be no information about the reversions associated with the temporary character of the differences between accounting and taxable income.

According to Wolk et al. (2008), the allocation of taxes on earnings, when there are temporal differences, cannot be interpreted as an income smoothing instrument, since management has no choice, as it a treatment that is the object of accounting standards. Beechy (2007) highlights that tax on earnings expenses are not comparable with others, since expenses are incurred with the expectation of generating revenues, which does not apply to tax on earnings expenses. Thus, although taxes are paid on taxable earnings and not on individual transactions, there is a direct economic relationship between the transactions presented in the statements for one period and their tax effect, and the cash flow effect should not be used as a 
basis without considering the future offsetting events (Brown et al., 1993).

On the other hand, the accounting literature also lists a series of opinions against recognizing DTAs, such as: the fact that deferment presupposes that there will be taxable income in the future and that the tax rules will be the same as in the present, which are questionable assumptions (Carey, 1944; Graul \& Lemke, 1976); taxes on earnings are paid in an aggregate amount, and not on individual items of revenue and expenses, while the temporal differences are based on specific items, for example the accruals not accepted in the tax system (Beechy, 2007); taxes on earnings should be considered as a "tax" on profitable operations and should be recorded as expenses when a profitable operation is carried out (Skinner \& Milburn, 2001); these taxes occur after the income is produced and not before, thus resembling dividends (Skinner \& Milburn, 2001); and there is no present obligation for the collecting agent to pay or reimburse the entity that recognizes the asset, otherwise that agent should recognize a liability (Skinner \& Milburn, 2001).

In addition, Healy and Palepu (2012) understand that increasing asymmetries in the criteria for accounting and tax measurement of earnings can signal a gradual deterioration of the quality of the earnings and capital reported over time, with a consequent reduction in financial information quality.

In summary, although this study does not aim to discuss the relevance or not of the accounting recognition of DTAs, a report on these theoretical arguments that question or support the economic basis for their recognition is important to highlight the peculiar nature of this type of asset, which gives rise to debates among accounting theorists.

\subsection{Accounting and Supervisory Treatment of DTAs}

Despite the recurring debates in the literature, there is a consensus in the various accounting frameworks International Accounting Standard 12 (IAS 12), Income Taxes (International Accounting Standards Board, 2001), Statement of Financial Accounting Standards No. 109 (SFAS 109), Accounting for Income Taxes (Financial Accounting Standards Board, 1992), and Technical Pronouncement CPC 32: Taxes on earnings (Accounting Pronouncements Committee - CPC, 2009) - regarding the recognition of DTAs, highlighting the following conditions: (i) recognition should occur in cases of probable recovery; (ii) deferment is based on the current or prevailing rates of tax on earnings; (iii) the record should be made for the value of the future tax effect of the temporary differences, limited to what will probably be consumed with future taxable earnings; (iv) they should not be discounted at present value.

For Brazilian banks, the rule that governs the accounting recognition of DTAs is National Monetary Council Resolution N. 3,059, of December $20^{\text {th }}$ of 2002 (CMN, 2002), and its updates, which in general follow the international accounting standards with additional specificities, including: the obligation for a technical study that demonstrates the probability of occurrence of taxable earnings that indicate the realization of the DTAs in up to 10 years; a history of taxable earnings in at least three of the last five financial periods; and DTA consumption accuracy of at least $50 \%$ of the values predicted in the technical study. This mitigates to some extent the risks associated with the implicit subjectivity in the DTA recognition and measurement process, although it does not eliminate these risks, given that the assumptions of the study are, by definition, also derived from judgements, estimates, and subjectivism, primarily if it is considered that such assets represent $44 \%$ of the NE of publicly-held Brazilian banks, on the June/2017 base date.

Within the scope of international banking regulation and with the aim of improving the capacity for banks to face financial crises and absorb shocks, Basel II introduced elements to raise the quality, consistency, and transparency of core capital, including the determination that DTAs be deducted from Reference Equity (RE), given the low quality attributed to these assets (BCBS, 2011).

To address this argument, some countries - particularly Italy, Spain, Portugal, Greece, and Brazil - have created laws authorizing banks' DTAs to be transformed into rights to government credit, in order to avoid their deduction from the composition of RE. Moody's Corporation (2015) notes, however, that although this aims to improve the quality of DTAs and qualifies them to compose regulatory capital, depending on the relevance of these assets, this measure does not fail to signal the weakening of banks' capital, given that: the realization of DTAs depends on future events and still uncertain taxable earnings that may take many years to materialize or not occur; the value of DTAs is not discounted at present value; the study conducted by banks to support the recognition of DTAs is based on subjective assumptions, and the reinforcement or reversion of accruals that give rise to new DTAs may cause undue fluctuations in the calculation of banks' regulatory capital; and the banks may commit to measures to force the realization of DTAs that can affect profitable and important portfolios for business continuity. 
Particularly in relation to the absence of an adjustment to the present value of DTAs highlighted by Moody's Corporation (2015), if these items become relevant balances in the equity structure - as is the case in the Brazilian banking industry - they may compromise the economic essence in the measurement of assets and the prediction of future cash flows as an appropriate representation of the value of assets in time (Black, 1966; Herring, Jacobs, Davidson \& Skelton, 1977; Kam, 1990; Revsine, 1969; Van Breda \& Ferris, 1989; Wolk et al., 2008).

\subsection{Studies and Informational Relevance of DTAs}

The informational relevance contained in financial statements consists of one of the main objectives of accounting. From this perspective, studies that seek to measure the reaction of investors to accounting information concentrate on identifying how and in what dimension they are useful for the user decision-making process (Dantas, Medeiros \& Lustosa, 2006). Regarding the utility, quality, and informational relevance of assets and DTLs, some empirical studies can be highlighted, such as those of Ayers (1998), Hanlon (2005), Skinner (2008), Chang, Herbohn, and Tutticci (2009), and Badenhorst and Ferreira (2016).

Ayers (1998) was innovative in evaluating the influence of DTLs on the capital market, identifying that net DTLs, disclosed in accordance with SFAS 109, are capable of providing additional relevant information for the market value of companies, and that when DTAs and DTLs are disclosed, without the offsetting of balances, and also when the accounts are adjusted to the current tax rates in the period of publication, the informational relevance is greater.

The role of the temporal differences in the quality and persistence of earnings, accruals, cash flows, and informational relevance were investigated by Hanlon (2005). The author found that, in periods with greater differences between accounting and taxable income, earnings persistence was lower than in periods with smaller differences, principally when accounting income is greater than taxable income, generating DTLs. In relation to the informational relevance, the results were not conclusive or varied. Generally, the temporal differences appear to influence the perception of investors with regard to earnings persistence, highlighting that the greatest differences appear not to impact the responses of investors regarding the inefficiency of earnings persistence.

The use of DTAs by Japanese banks in the 1998 international financial crisis period was evaluated by
Skinner (2008). The evidence showed how political and regulatory forces influenced the application of accounting rules that affect financial reports practices in the capital market. It was revealed that the weakest banks recognized high levels of DTAs in the crisis period, despite the low expectation for future earnings that would justify this, thus culminating, in subsequent financial periods, in the impossibility of their realization.

Chang et al. (2009) investigated the informational relevance of the deferred taxes reported by Australian companies in the period from 2001 to 2004, obtaining evidence that DTAs in a way represent a type of "saving" for future taxes, and that the non-recognition of these assets may be interpreted as a sign of probable future losses. Generally, the results provided evidence that the market perceives DTAs as a probable reduction of future taxes and DTLs as future tax costs.

Given the importance of the informational relevance of DTAs, Badenhorst and Ferreira (2016) reviewed the literature on these assets and investigated the perception of investors during the 2007 and 2008 financial crisis. The tests revealed that, in times of crisis, the informational relevance of DTAs has an impact on market agents, revealing a negative association between the recognition of these assets and the market value of companies. The study comparatively evaluated Australian companies and ones from the United Kingdom, finding that the regulatory environment influences the reaction of investors.

In Brazil, DTAs have been the object of a number of studies. Moura and Martinez (2006) specifically addressed the banking industry, but with a focus on evaluating the impact of DTAs on the risk structure of Brazilian financial institutions, in particular on the determination of regulatory capital. Other studies have concentrated on analyzing the impact of recognizing DTAs on financial structure and economic performance (Kronbauer, Souza, Webber \& Ott, 2012), by identifying determinants of the recognition of these assets (Kronbauer, Souza, Alves \& Rojas, 2010; Schuh, Ribeiro, Simon \& Kronbauer, forthcoming) or by evaluating their use for earnings management purposes (Oliveira, Lemes \& Almeida, 2008). As is perceived, although the DTA issue is not necessarily unusual in the Brazilian literature, the studies can still be considered as incipient, principally if we specifically consider the question of value relevance.

Considering this context, it is verified that the literature still presents inconclusive results regarding the way the market evaluates the relevance of DTAs in the equity structure of companies, and that studies about banks are less developed. There are theoretical 
arguments and empirical evidence that support both a positive and negative association between the stock of DTAs and the market value of companies, but there is practically no evidence regarding the banking industry
- a segment in which the theoretical, regulatory, and empirical discussions (Skinner, 2008) indicate that DTAs compromise the quality of capital, one of the most relevant elements of the financial solidity of these entities.

\section{METHODOLOGICAL PROCEDURES}

Given the intention to investigate the informational relevance of DTAs in terms of the market value of publiclyheld Brazilian banking institutions, in this section the research hypothesis is formulated, the models for carrying out the tests and the criteria for measuring the variables are defined, and the sample is specified.

\subsection{Development of the Research Hypothesis}

As highlighted in section 2, there are theoretical arguments and empirical evidence - not specifically concerning banks - that support the expectation of a positive market reaction to the stock of companies' DTAs as they: suggest a predictability horizon for future income (Chang et al., 2009); convey the perception of earnings persistence (Ayers, 1998; Badenhorst \& Ferreira, 2016; Beaver, 1998; Jensen \& Meckling, 1976); create the sensation of maximizing the current value of the firm (Cao \& Narayanamoorthy, 2006; Watts \& Zimmerman, 1986); and avoid excessive earnings fluctuations (Wolk et al., 2008).

On the other hand, the literature lists a series of arguments that question the quality of the DTAs recognized by banking institutions, including:

- Significant DTA amounts represent an additional risk to banking entities, due to the sterility of these items, which deprives them of economic substance and compromises the quality of the capital and earnings of banks (Moody's Corporation, 2015; Skinner, 2008; Standard \& Poor's Ratings Services, 2016).

- Measuring DTAs by their nominal value would go against the economic essence of future cash flow predictions, as an appropriate representation of the value of assets in time (Herring et al., 1977; Van Breda \& Ferris, 1989).

- Continuous and increasing asymmetries in the criteria for the accounting and tax measurement of earnings may signal a reduction in financial information quality, with these being distortion vectors in the financial statements (Healy \& Palepu, 2012).

- The capacity to generate economic benefits and effective control by the entity is questionable in relation to DTAs (Healy \& Palepu, 2012).

- The assumptions that support the deferment of earnings expenses are subjective and questionable, such as the presumption of future earnings (Carey, 1944; Graul \& Lemke, 1976).

Considering these arguments, added to the high representativeness of these assets in the equity structure of Brazilian banks, it is possible to infer that investors evaluate the stock of DTAs as an element that compromises the quality of the capital and earnings of banking institutions, exercising a negative influence over the formation of the market value of these entities, which supports the following research hypothesis to be empirically tested:

$\mathrm{H}_{1}$ : in the Brazilian capital market, there is a negative association between the magnitude of DTAs in the equity structure of banks and the market value of these entities.

\subsection{Definition of the Models for the Empirical Tests}

To empirically test the informational value of the DTAs and the relationship predicted in hypothesis $\mathrm{H}_{1}$, the MTB model will be used, which considers that the market value of entities is influenced by the main market and accounting information available, and, in addition, the Ohlson model (1995), idealizing the assumption that the company's market value can be explained by its accounting information.

The different theoretical frameworks of the models (MTB and Ohlson) and variables applied in the investigation aim to explore possibilities of a relationship between the market value of the banks and the stock of DTAs, in order to increase the robustness of the empirical evidence. 


\subsubsection{MTB Model}

The MTB model was developed based on the studies of Fama and French (1992, 1995), Edvinsson and Malone (1997), and Roos, Edvinsson, and Dragonetti (1997), and considers that the market value of the shares over the NE of the entities is influenced by the main market and accounting information available.

$$
\begin{gathered}
M T B_{i, t}=\beta_{0}+\beta_{1} D T A_{i, t}+\beta_{2} \text { Size }_{i, t}+\beta_{3} B I_{i, t}+\beta_{4} R O E_{i, t}+\beta_{5} D I V_{i t}+\beta_{6} O p C_{i t}+ \\
B_{7 I B O V}+\beta_{8} G D P_{t}+\beta_{9} \text { Selic }_{t}+\beta_{10} C r i E x_{t}+\beta_{11} P u b_{i}+\varepsilon_{i t}
\end{gathered}
$$

in which $M T B_{\mathrm{i}, \mathrm{t}}$ is the ratio between the market value and accounting value (NE) of bank $i$ in quarter $t$ (last working day); $D T A_{\mathrm{i}, \mathrm{t}}$ is the DTA stock of bank $i$ in quarter $t$ measured as the proportion of total assets and, alternately, of NE; Size $e_{\mathrm{i}, \mathrm{t}}$ is the size of the banks calculated by the natural logarithm of the total assets of bank $i$ in quarter $t ; B I_{\mathrm{i}, \mathrm{t}}$ is the capitalization level of bank $i$ in quarter $t$ represented by the Basel Index; $R O E_{\mathrm{i}, \mathrm{t}}$ is the profitability level of bank $i$ in quarter $t$ measured by the return generated over NE (return on equity - division between the net income for the period and the average $\mathrm{NE}$ ); $D I V_{\mathrm{it}}$ is the dividend paid per share in bank $i$ in quarter $t ; O p C_{i t}$ is the share of the credit portfolio in the equity structure of bank $i$ in quarter $t ; I B O V_{\mathrm{t}}$ (Bovespa Index - Ibovespa) corresponds to the main performance indicator of the most tradeable and representative assets in the Brazilian capital market obtained by the quarterly percentage variation of the theoretical assets portfolio of the São Paulo Stock, Commodities, and Futures Exchange (BM\&FBovespa); $G D P_{\mathrm{t}}$ is the variation in gross domestic product (GDP) in quarter $t$, conveying the country's level of economic activity in the period; Selic $c_{\mathrm{t}}$ is the variation in the economy's basic interest rate, the Special System for Settlement and Custody (Selic), in quarter t; CriEx $x_{\mathrm{t}}$ is the dummy variable representative of the international financial crisis period, taking the value 1 for the years 2008 to 2010 and 0 for the rest; $P u b_{i}$ is the dummy variable representative of the control of the institution's capital, taking the value 1 for banks under public control and 0 for the rest; $\varepsilon_{\mathrm{it}}$ is the error term of the regression, assuming residual normality, that is, $\sim \mathrm{N}(0, \sigma 2)$.

The variable of interest, $D T A$, is measured, alternately, in two ways: as a proportion of total assets (DTA/TA) or of NE (DTA/NE), with the aim of exploring by different means the representativeness of DTAs in the equity structure of the banks. The idea is to increase the robustness of the empirical evidence, which will enable it to be concluded whether the stock of these balance sheet items is relevant for explaining the behavior of the market value of the Brazilian banks and whether this relationship is negative, as $\mathrm{H}_{1}$ predicts.

With the aim of ensuring the robustness of the findings in relation to the DTA variable of interest, the control variables Size, BI, ROE, DIV, OpC, IBOV, GDP, Selic,
CriEx, and Pub were added to the model in order to capture the effects of these variables on the market value of the banks included in the sample.

Regarding the specific variables of the banking institutions, the inclusion of the Size variable is justified by the fact that, as Berk (1997) stipulates, the size of the banks is expected to explain differences in the levels of proportional valuation of these entities. With relation to the capitalization level $(B I)$, the assumption set out by Akhigbe, Madura, and Marciniak (2012) is that higher levels of capital result in the margins of return being compromised, which should negatively influence the share price. For $R O E$, the expectation is that investors tend to value companies with greater profitability and return, and there should be a positive association with the market value of the banks. Regarding dividends, although there are different assumptions in the literature (Silva \& Dantas, 2015), the dividends policy is expected to positively influence the market value of the banks, due to the financial realization of benefits. For the credit portfolio share $(O p C)$ in the banks' equity structure, competing associations with market value are accepted: a positive one, due to the fact that they represent the operations with the greatest profit margin in the banks; and a negative one, as they characterize the portfolio with the greatest risk of losses in banks. The capital control condition of the banks is captured by the $P u b$ variable, for which a negative relationship with the market value of the banks is expected, based on the assumption that investors more positively evaluate private banks, as they do not answer to the interests of the government controller.

Market and macroeconomic variables were also incorporated. For market return (IBOV), the expected association is positive, as it represents the natural effect of market behavior on the market value of the listed banks. The GDP variable aims to control the effects of the level of economic activity on the market value of the banks, and a positive relationship is expected between the variables. For the Selic, a negative relationship with market value is expected, as it conveys a more instable environment and also due to the fact that the basic interest rate tends to be more quickly reflected in the banks' resource capturing instruments than in assets, which tend to have longer timescales. Regarding the CriEx variable, its inclusion is 
warranted due to the findings of Badenhorst and Ferreira (2016) in the Australian market.

It should be noted that the decision was made not to include the specific variable to control the economic and political crisis period verified in Brazil, particularly from 2015 onwards, considering that the GDP variable, by capturing the variations in the level of economic activity, ultimately controls such effects.

\subsubsection{Ohlson Model (1995)}

As an alternative mechanism for empirically testing the relationship predicted in the hypotheses formulated, the Ohlson model (1995), modified by Collins, Maydew, and Weiss (1997), will be used, which considers the relationship between the company's accounting information and its market value. In this model, the formation of the company's market value is composed of the accounting income and NE. Amir, Kirschenheiter, and Willard (2001) and Chang et al. (2009) conducted studies regarding the informational relevance of deferred taxes using derivations of the Ohlson model (1995).

For the purposes of this study, following Collins et al. (1997), the original Ohlson model (1995) was complemented with the inclusion of the DTAs per share among the regressors, as well as adjusting the representative variable of NE by excluding the effects of the variable of interest, the DTAs, leading to the following expression:

$$
M V s h_{i, t}=\beta_{0}+\beta_{1}\left(N E s h_{i, t}-D T A s h_{i, t}\right)+\beta_{2} N I s h_{i, t}+\beta_{3} D T A s s h_{i, t}+\varepsilon_{i, t}
$$

in which $M V s h_{\mathrm{i}, \mathrm{t}}$ is the market value per share of bank $i$ at the end (last working day) of quarter $t ; N E s h_{\mathrm{i}, \mathrm{t}}$ is the NE per share of bank $i$ at the end of quarter $t ; N I s h_{\mathrm{i}, \mathrm{t}}$ is the net income per share of bank $i$ at the end of quarter $t$; $D T A s h_{\mathrm{i}, \mathrm{t}}$ is the deferred tax assets per share of bank $i$ at the end of quarter $t$; and $\varepsilon_{\mathrm{i}, \mathrm{t}}$ is the error term of the regression, assuming residual normality, that is, $\sim \mathrm{N}(0, \sigma 2)$.

According to the theoretical foundations of hypothesis $\mathrm{H}_{1}$, the variable of interest DTAsh is expected to have a negative sign. In addition, as the Ohlson model (1995) predicts, positive signs are expected for $\beta_{1}$ and $\beta_{2}-$ representative parameters of the NEsh variables adjusted by the deduction of DTAsh and NIsh.

\subsection{Sample Selection and Data Source}

To run the empirical tests, the sample is composed of publicly-held banks listed on the B3, considering the March 2000 to June 2017 reference period, with quarterly data periodicity. Data on banks that did not have information for the whole sample period were used in accordance with the opening or closing of capital, discontinuation (through acquisition, merger, incorporation, and liquidation processes etc.), or constitution in the time interval examined.

The data used in the research were obtained from the entities' financial statements, from the webpages of the Brazilian Central Bank and the Brazilian Securities and Exchange Commission (CVM in Portuguese) on the internet, and from the Economatica ${ }^{\circledR}$ database.

\section{CALCULATION AND ANALYSIS OF THE RESULTS}

Before estimating the models, the following procedures were adopted to ensure the robustness and accuracy of the results calculated: $1 \%$ winsorization in the database as a way of treating outliers, following Hastings, Mosteller, Turkey, and Winsor (1947), in order to verify whether the results found in the complete database would not be determined by outliers; ADF-Fisher and PP-Fisher tests in order to verify fulfilling the assumption of stationarity of the series, ensuring the non-occurrence of spurious regressions - the results showed that the series are stationary; variance inflation factor (VIF) test, which evaluates the collinearity between the series - the results showed that there was no risk of multicollinearity; Chow test, following Dantas, Galdi, Capelletto, and Medeiros (2013), to evaluate whether the use of panel data provides an informational gain - the results revealed that using panel data improves the estimations; Hausman test
(1978) to define the panel data method applicable to the models, whether this is fixed effects or variable effects - the results confirmed that using fixed effects would be more appropriate; use of the seemingly unrelated regressions (SUR) and panel corrected standard error (PCSE) standard errors method in the cross-sectional fixed effects, which generates robust parameters, thus mitigating the risk of heteroskedasticity and autocorrelation in the residuals, even though they may be present.

\subsection{MTB Model}

The sequence for calculating the results is initiated with the descriptive statistics of the variables that compose the MTB 1 model, including the two forms of measurement: the complete database and the $1 \%$ winsorized one. The results are summarized in Table 1. 
Table 1

Descriptive statistics of model 1 for the complete and winsorized databases

\begin{tabular}{|c|c|c|c|c|c|c|c|c|c|c|c|c|c|}
\hline \multicolumn{14}{|c|}{ Complete database } \\
\hline & MTB & DTA/TA & $D T A / N E$ & Size & $B I$ & $R O E$ & $D I V$ & OpC & $I B O V$ & $G D P$ & Selic & CriEx & Pub \\
\hline Mean & 1.31 & 0.03 & 0.27 & 17.30 & 0.11 & 0.03 & 0.15 & 0.38 & 0.02 & 0.01 & 0.00 & 0.20 & 0.36 \\
\hline Median & 1.00 & 0.03 & 0.25 & 16.51 & 0.11 & 0.04 & 0.04 & 0.37 & 0.02 & 0.00 & 0.00 & 0.00 & 0.00 \\
\hline Maximum & 6.76 & 0.11 & 1.68 & 21.09 & 0.39 & 0.41 & 5.13 & 0.72 & 0.39 & 0.05 & 0.06 & 1.00 & 1.00 \\
\hline Minimum & 0.03 & 0.00 & 0.00 & 14.34 & 0.04 & -2.48 & 0.00 & 0.07 & -0.27 & -0.05 & -0.01 & 0.00 & 0.00 \\
\hline Standard deviation & 0.92 & 0.02 & 0.22 & 1.77 & 0.05 & 0.09 & 0.36 & 0.11 & 0.13 & 0.03 & 0.01 & 0.40 & 0.48 \\
\hline \multicolumn{14}{|c|}{ Winsorized database $(1 \%)$} \\
\hline Mean & 1.29 & 0.02 & 0.26 & 17.29 & 0.11 & 0.03 & 0.13 & 0.38 & 0.02 & 0.00 & 0.00 & 0.19 & 0.36 \\
\hline Median & 1.00 & 0.02 & 0.25 & 16.50 & 0.10 & 0.03 & 0.03 & 0.36 & 0.02 & 0.00 & 0.00 & 0.00 & 0.00 \\
\hline Maximum & 4.31 & 0.08 & 1.07 & 21.00 & 0.31 & 0.16 & 1.65 & 0.67 & 0.38 & 0.05 & 0.05 & 1.00 & 1.00 \\
\hline Minimum & 0.25 & 0.00 & 0.00 & 14.34 & 0.03 & -0.07 & 0.00 & 0.12 & -0.27 & -0.05 & -0.00 & 0.00 & 0.00 \\
\hline Standard deviation & 0.86 & 0.01 & 0.18 & 1.77 & 0.04 & 0.03 & 0.25 & 0.11 & 0.12 & 0.02 & 0.01 & 0.39 & 0.48 \\
\hline
\end{tabular}

DTA $/ T A=$ stock of deferred tax assets (DTAs) over total assets; DTA/NE = stock of DTAs over net equity (NE); CriEx = dummy variable taking the value 1 in the years from 2008 to 2010 and 0 in the rest; DIV = dividends paid per share; $B I=$ capitalization level, proxy for the Basel Index; IBOV = Bovespa Index (Ibovespa), performance indicator for the most tradeable assets in the Brazilian capital market; MTB (Market-to-Book) = ratio between market value and accounting value $(N E) ; O p C=s h a r e$ of the credit portfolio in the banks' equity structure; GDP = variation in gross domestic product, conveying the level of economic activity; Pub = dummy variable taking the value 1 for public banks and 0 for the rest; ROE = level of profitability measured by the return on NE; Selic = Special System for Settlement and Custody (the economy's basic interest rate); Size = measure of size of banks calculated via the natural logarithm of total assets.

Source: Elaborated by the authors.

The descriptive statistics of the dependent variable $(M T B)$ reveal that the banks' market value corresponds, on average, to something around $30 \%$ above the accounting value, although with considerable variability. Given this dispersion characteristic, the alternative use of the winsorized database becomes more relevant, in order to evaluate whether the results identified in the complete database would persist when treating the outliers.

With relation to the study's variable of interest, the data reveal that DTAs represent, on average, $2 \%$ of the banks' total assets (DTA/TA), with a maximum of $11 \%$, and $26 \%$ of their NE (DTA/NE), with a peak of $168 \%$ - a situation in which deferred taxes exceed the institution's NE by $68 \%$. These descriptive statistics, revealing the relative importance of these assets in the equity structure, may signal difficulties in consuming the DTAs, given the need to achieve the taxable earnings projected for the long term and potential decapitalization problem of the banks.

Given the regulation imposed by the CMN, if the bank does not achieve the taxable income projected to consume the DTAs, it can be impeded from asseting new items and, in an extreme scenario, be obliged to lower the values asseted (entirely or partly), with a direct impact on earnings and consequent weakening of capital. In this DTA relevance scenario, the banks are continuously required to achieve increasing taxable income to consume these assets, which may lead to bolder accounting practices.

From an opposite perspective, if, in a particular period, the bank obtains expressive taxable income, it can envisage the possibility of increasing the consumption of DTAs, which would represent a reduction in the tax payable in that period. This can stimulate the bank to promote actions that bring forward the consumption of these assets, such as the alienation of portfolios or other mechanisms accepted by the tax rules for deducting DTAs in tax payable.

\subsubsection{Estimations of the model}

To conclude regarding hypothesis $\mathrm{H}_{1}$, the MTB 1 model was estimated considering combinations of two alternative ways of measuring the relevance of DTAs (DTA/TA and DTA/NE), of the estimation using panel data with cross-sectional fixed effects and by period of use of the complete database and the database winsorized at $1 \%$. The results are consolidated in Table 2 . 
Table 2

Estimations of model 1 using panel data with cross-sectional fixed effects (FEs) and by period

\begin{tabular}{|c|c|c|c|c|c|c|c|c|}
\hline \multicolumn{9}{|c|}{ Model tested } \\
\hline \multicolumn{9}{|c|}{$M T B_{i, t}=\beta_{0}+\beta_{1} D T A_{i, t}+\beta_{2} S_{i z e},+\beta_{3} B I_{\mathrm{i}, \mathrm{t}}+\beta_{4} R O E_{\mathrm{i}, \mathrm{t}}+\beta_{5} D I V_{\mathrm{i}, \mathrm{t}}+\beta_{6} O p C_{i t}+\beta_{7} I B O V_{t}+\beta_{8} G D P_{\mathrm{t}}+\beta_{9} S_{e l i c}+\beta_{10} C_{r i E x_{\mathrm{t}}}+\beta_{11} P u b_{\mathrm{t}}+\varepsilon_{\mathrm{it}}$} \\
\hline \multirow{3}{*}{ Variable } & \multicolumn{4}{|c|}{ Variable of interest: DTA/TA } & \multicolumn{4}{|c|}{ Variable of interest: DTA/NE } \\
\hline & \multicolumn{2}{|c|}{ Cross-sectional FEs } & \multicolumn{2}{|c|}{ Period FEs } & \multicolumn{2}{|c|}{ Cross-sectional FEs } & \multicolumn{2}{|c|}{ Period FEs } \\
\hline & $\begin{array}{l}\text { Complete } \\
\text { database }\end{array}$ & $\begin{array}{l}\text { Winsorized } \\
\text { database }\end{array}$ & $\begin{array}{l}\text { Complete } \\
\text { database }\end{array}$ & $\begin{array}{c}\text { Winsorized } \\
\text { database }\end{array}$ & $\begin{array}{l}\text { Complete } \\
\text { database }\end{array}$ & $\begin{array}{c}\text { Winsorized } \\
\text { database }\end{array}$ & $\begin{array}{l}\text { Complete } \\
\text { database }\end{array}$ & $\begin{array}{c}\text { Winsorized } \\
\text { database }\end{array}$ \\
\hline \multirow{3}{*}{ C } & 10.170 & 9.428 & -1.677 & -1.427 & 10.290 & 9.347 & -2.023 & -1.571 \\
\hline & $(0.000)$ & $(0.000)$ & $(0.000)$ & $(0.000)$ & $(0.000)$ & $(0.000)$ & $(0.000)$ & $(0.000)$ \\
\hline & $* * *$ & ${ }_{* * *}$ & ${ }_{* * *}$ & $* * *$ & ${ }_{* * *}$ & ${ }_{* * *}$ & ${ }_{* * *}$ & $* * *$ \\
\hline \multirow{3}{*}{$D T A / T A$} & -11.459 & -11.296 & -6.119 & -4.275 & & & & \\
\hline & $(0.000)$ & (0.000) & (0.000) & (0.000) & & & & \\
\hline & $* * *$ & $* * *$ & $* * *$ & $* * *$ & & & & \\
\hline \multirow{3}{*}{ DTA/NE } & & & & & -0.945 & -0.932 & -0.430 & -0.197 \\
\hline & & & & & $(0.000)$ & $(0.000)$ & $(0.000)$ & $(0.044)$ \\
\hline & & & & & *** & $* * *$ & $* * *$ & $* *$ \\
\hline \multirow{3}{*}{ Size } & -0.480 & -0.445 & 0.207 & 0.179 & -0.481 & -0.436 & 0.218 & 0.179 \\
\hline & (0.000) & (0.000) & (0.000) & (0.000) & (0.000) & (0.000) & (0.000) & (0.000) \\
\hline & ${ }_{* * *}$ & $* * *$ & ${ }_{* * *}$ & $* * *$ & $* * *$ & $* * *$ & $* * *$ & $* * *$ \\
\hline \multirow{3}{*}{$B I$} & -1.655 & -1.127 & & & -3.002 & -2.544 & & \\
\hline & (0.003) & $(0.054)$ & & & (0.000) & $(0.000)$ & & \\
\hline & ${ }_{* * *}$ & * & & & ${ }^{* * *}$ & ${ }_{* * *}$ & & \\
\hline \multirow{3}{*}{$R O E$} & 0.613 & 2.465 & 0.857 & 5.674 & 0.641 & 2.649 & 0.897 & 5.964 \\
\hline & (0.000) & (0.000) & (0.000) & (0.000) & (0.000) & (0.000) & (0.000) & (0.000) \\
\hline & $* * *$ & $* * *$ & $* * *$ & $* * *$ & ${ }_{* * *}$ & $* * *$ & ${ }_{* * *}$ & $* * *$ \\
\hline \multirow{2}{*}{ DIV } & -0.052 & -0.012 & -0.116 & -0.068 & -0.045 & -0.009 & -0.142 & -0.098 \\
\hline & $(0.217)$ & $(0.852)$ & $(0.028)$ & $(0.379)$ & $(0.252)$ & $(0.886)$ & $(0.013)$ & $(0.220)$ \\
\hline \multirow{3}{*}{ OpC } & -0.084 & -0.139 & -1.204 & -1.144 & -0.117 & -0.095 & -0.975 & -0.975 \\
\hline & $(0.747)$ & $(0.570)$ & $(0.000)$ & $(0.000)$ & $(0.646)$ & (0.698) & $(0.000)$ & $(0.000)$ \\
\hline & & & ${ }_{* * *}$ & $* * *$ & & & $* * *$ & $* * *$ \\
\hline \multirow{3}{*}{$I B O V$} & 1.021 & 0.902 & & & 0.998 & 0.895 & & \\
\hline & (0.000) & (0.000) & & & $(0.000)$ & $(0.000)$ & & \\
\hline & $* * *$ & $* * *$ & & & ${ }_{* * *}$ & $* * *$ & & \\
\hline \multirow{2}{*}{$G D P$} & 1.236 & 0.934 & & & 1.277 & 0.963 & & \\
\hline & $(0.292)$ & (0.386) & & & $(0.275)$ & $(0.375)$ & & \\
\hline \multirow{3}{*}{ Selic } & -18.900 & -18.199 & & & -18.577 & -17.734 & & \\
\hline & $(0.000)$ & $(0.000)$ & & & $(0.000)$ & $(0.000)$ & & \\
\hline & $* * *$ & $* * *$ & & & ${ }^{* * *}$ & ${ }_{* * *}$ & & \\
\hline \multirow{2}{*}{ CriEx } & 0.071 & 0.0763 & & & 0.080 & 0.087 & & \\
\hline & $(0.387)$ & $(0.316)$ & & & $(0.329)$ & $(0.259)$ & & \\
\hline \multirow{3}{*}{ Pub } & & & 0.041 & -0.060 & & & 0.088 & -0.043 \\
\hline & & & $(0.337)$ & $(0.159)$ & & & $(0.035)$ & $(0.321)$ \\
\hline & & & & & & & $* *$ & \\
\hline Period & $2000 / 17$ & $2000 / 17$ & $2000 / 17$ & 2000/17 & $2000 / 17$ & 2000/17 & $2000 / 17$ & $2000 / 17$ \\
\hline N. Obs. & 1.676 & 1.676 & 1.676 & 1.676 & 1.676 & 1.676 & 1.676 & 1.676 \\
\hline $\mathrm{R}^{2}$ & 0.648 & 0.689 & 0.452 & 0.509 & 0.646 & 0.684 & 0.449 & 0.505 \\
\hline
\end{tabular}


Table 2

Cont.

\begin{tabular}{|c|c|c|c|c|c|c|c|c|}
\hline \multicolumn{9}{|c|}{ Model tested } \\
\hline \multicolumn{9}{|c|}{$M T B_{i, t}=\beta_{0}+\beta_{1} D T A_{i, t}+\beta_{2} S_{i z e},+, \beta_{3} B I_{\mathrm{i}, \mathrm{t}}+\beta_{4} R O E_{\mathrm{i}, \mathrm{t}}+\beta_{5} D I V_{\mathrm{i}, \mathrm{t}}+\beta_{6} O p C_{i t}+\beta_{7} I B O V_{t}+\beta_{8} G D P_{\mathrm{t}}+\beta_{9} S_{e l i c}+\beta_{10} C_{r i E x_{\mathrm{t}}}+\beta_{11} P b_{\mathrm{t}}+\varepsilon_{\mathrm{it}}$} \\
\hline \multirow{3}{*}{ Variable } & \multicolumn{4}{|c|}{ Variable of interest: DTA/TA } & \multicolumn{4}{|c|}{ Variable of interest: DTA/NE } \\
\hline & \multicolumn{2}{|c|}{ Cross-sectional FEs } & \multicolumn{2}{|c|}{ Period FEs } & \multicolumn{2}{|c|}{ Cross-sectional FEs } & \multicolumn{2}{|c|}{ Period FEs } \\
\hline & $\begin{array}{l}\text { Complete } \\
\text { database }\end{array}$ & $\begin{array}{c}\text { Winsorized } \\
\text { database }\end{array}$ & $\begin{array}{l}\text { Complete } \\
\text { database }\end{array}$ & $\begin{array}{c}\text { Winsorized } \\
\text { database }\end{array}$ & $\begin{array}{l}\text { Complete } \\
\text { database }\end{array}$ & $\begin{array}{c}\text { Winsorized } \\
\text { database }\end{array}$ & $\begin{array}{l}\text { Complete } \\
\text { database }\end{array}$ & $\begin{array}{c}\text { Winsorized } \\
\text { database }\end{array}$ \\
\hline $\mathrm{R}^{2}$ adjusted & 0.638 & 0.680 & 0.426 & 0.486 & 0.636 & 0.675 & 0.424 & 0.482 \\
\hline F statistic & 65.283 & 78.450 & 17.608 & 22.120 & 64.638 & 76.618 & 17.425 & 21.801 \\
\hline F (p-value) & 0.000 & 0.000 & 0.000 & 0.000 & 0.000 & 0.000 & 0.000 & 0.000 \\
\hline
\end{tabular}

DTA/TA = stock of deferred tax assets (DTAs) over total assets; DTA/NE = stock of deferred tax assets (DTAs) over net equity ; CriEx = dummy variable taking the value 1 in the years from 2008 to 2010 and 0 in the rest; DIV = dividends paid per share; BI = capitalization level, proxy for the BI; IBOV = Bovespa Index (Ibovespa), performance indicator of the most tradeable assets in the Brazilian capital market; MTB (Market-to-Book) = ratio between market value and accounting value (net equity - NE); OpC = share of the credit portfolio in the banks' equity structure; GDP = variation in gross domestic product, conveying the level of economic activity; Pub = dummy variable taking the value 1 for public banks and 0 for the rest; ROE = level of profitability measured by the return on NE; Selic = Special System for Settlement and Custody (the economy's basic interest rate); Size = measure of the size of the banks calculated via the natural logarithm of total assets.

***, **, *: 1, 5, and 10\% level of significance, respectively. P-value in parentheses.

Source: Elaborated by the authors.

The results reveal that there is a negative and statistically relevant relationship between the market value and the share of DTAs in the equity structure of the Brazilian banks. This evidence persists, independently of the way deferred taxes are measured (as a share of total assets or of NE), of the estimation method (crosssectional fixed effects or by period), and of the database considered (original or winsorized). The combination of this information shows that the banks' DTA stock, besides having statistically significant informational value for capital market agents, weighs negatively on the market value of these entities, corroborating hypothesis $\mathrm{H}_{1}$.

This indicates that, for the Brazilian capital market, significant DTA amounts are understood as an additional risk for banking entities, which can be explained by some characteristics of these assets, including: (i) the sterility of these items (non-generators of income) for banking institutions, which reduces NE and earnings quality; (ii) the questions regarding the capacity of DTAs to generate future economic benefits and effective control by the entity over these assets; (iii) the potential reduction in the informational quality of financial statements, since measuring these assets by their nominal value would go against the economic essence of future cash flow predictions, as an appropriate representation of the value of assets in time; and (iv) the subjective and questionable assumptions that support the recognition of DTAs, including the presumption of future taxable income.

These results are coherent with the line of authors, organisms, and ratings agencies that question DTAs, especially in banking institutions, such as Carey (1944), Black (1966), Revsine (1969), Graul and Lemke (1976), Herring et al. (1977), Beechy (2007), Skinner (2008), BCBS (2011), Healy and Palepu (2012), Moody's Corporation (2015), and Standard \& Poor's Ratings Services (2016).

Regarding the coefficients of variation of interest of the study, DTA/TA and DTA/NE, it is important to highlight that the differences of dimensions between them are explained by the denominator effect of these variables and of the dependent variable, MTB. In the case of DTA/ $N E$, as the NE of the entities has the same denominator as the MTB variable, the coefficient more clearly conveys the association between the representativeness of DTAs in NE and the pricing of this book value by the market. Although with relevant variations, depending on whether the control for individual heterogeneity is carried out with the cross-sectional or period fixed effects estimation, the coefficients reveal what the impact is of an increase in the representativeness of DTAs in NE in the way this same $\mathrm{NE}$ is priced. The negative signs mean that the greater the representativeness of DTAs in the composition of $\mathrm{NE}$, the worse the perception of investors regarding the market value of the book value. In the case of the first estimation (cross-sectional fixed effects), for example, for each percentage point increase in the share of DTAs in relation to NE, the market value of each unit of NE is reduced by 0.9 percentage point. That is, the greater the share of DTAs in the NE, the lower the market value of that NE. 
When the variable of interest is $D T A / T A$, this relationship is not as direct. This is because a variation in the share of DTAs in the composition of total assets should more than proportionally affect the market value in relation to NE (MTB), given the effect of the leveraging of the entities' own capital. The average number of the $B I$ variable, calculated by the NE/TA ratio, helps explain this logic. According to Table 1, NE represents, on average, $11 \%$ of total assets. Thus, by isolating the effects of the denominator in the $M T B$ and DTA/TA variables, the relationship between DTAs (without the TA denominator) and market value (without the NE denominator) can be found more directly, based on the multiplication of the coefficient of the DTA/TA variable $(-11.459,-11.296$, -6.119 , and -4.275$)$ by the average $B I(11 \%)$, which would give something around $-1.2604,-1.2425,-0.6731$, and -0.4702 in the four estimations of Table 2, respectively, resulting in coefficients equivalent to those calculated in relation to the DTA/NE variable.

Regarding the control variables, significant positive associations were identified between the dependent variable $(M T B)$ and the variables representative of $R O E$ and of the evolution of the IBOV. In the case of $R O E$, the results confirm the assumption that investors tend to value more profitable companies with higher return, as well as revealing the importance of the performance of the banks for capital market agents. The positive relationship with the $I B O V$ was also expected, due to the natural reflection of the market index in the value of these listed entities.

Conversely, significant negative relationships were found between the MTB and the BI, Selic, and OpC variables. The negative association between the dependent variable and the capitalization level (BI) confirms the arguments of Akhigbe, Madura, and Marciniak (2012) that the greater the bank's own capital, the greater the sensation of risk to which the banking entity would be exposed, in addition to higher levels of capital resulting in the margins of return being compromised, which should negatively influence the share price. This same risk argument can help explain the negative relationship between $M T B$ and $O p C$, given that the greater the share of the credit portfolio in the bank's equity structure, the greater the associated perception of risk. In the case of the Selic, the negative sign is coherent with the assumption that the effects of variations in the basic interest rate are more quickly reflected in the cost of raising funds than in the average credit rates, given the impact of the credit stock, which tends to produce inverse effects on the profitability level.
With relation to the Size variable, the results are contradictory, depending on the estimation method used: using fixed effects in the period, the results revealed a negative association with the $M T B$ variable, confirming the predictions of Berk (1997) that smaller banks are proportionally more valued; and using cross-sectional fixed effects, the estimations showed a positive relationship with the dependent variable, suggesting that size can indicate a sensation of solidity and confidence, which is essential in the financial intermediation sector, and that this is reflected in the pricing of their shares. These results reveal that the inclusion or exclusion of other control variables, warranted by the estimation method, influences the relationship between the size of the banks and their market values.

Finally, the results show that the dependent variable, $M T B$, has no significant relationship with: (i) the dividends distributed per share by the banks (DIV), confirming the irrelevance of the dividends policy for the pricing of shares revealed in the findings of Silva and Dantas (2015); the level of economic activity $(G D P)$, revealing that the market value of the book value of the Brazilian banks is indifferent to variations in the level of growth of the economy; the dummy variable representative of the most intense crisis period in the international markets (CriEx), not confirming the evidence of a positive association between these variables, identified by Badenhorst and Ferreira (2016) in the Australian market; and the condition of the banks being under public control $(P u b)$, revealing that the equity structure is not enough to determine the behavior of the market value of the Brazilian banks.

\subsection{Ohlson Model (1995)}

Despite the set of estimations of the MTB model confirming the negative relationship between the DTA stock and the market value of the banks, as an alternative mechanism to test the formulated hypotheses another type of theoretical formulation will be used to verify whether the earnings persist or not, using the Ohlson model (1995), whose theoretical framework is widely used to investigate the value relevance of accounting information for the capital market, based on the assumption that NE and earnings over time are capable of explaining the market value of companies.

In the same way as was adopted in section 4.1 , the estimation of model 2 also uses a complete database and another one winsorized at $1 \%$. Table 3 consolidates the descriptive statistics of the variables of the model. 
Table 3

Descriptive statistics of model 2 for the complete and winsorized databases

\begin{tabular}{|c|c|c|c|c|c|c|c|c|}
\hline \multirow{2}{*}{ Variable } & \multicolumn{4}{|c|}{ Complete database } & \multicolumn{4}{|c|}{ Winsorized database $(1 \%)$} \\
\hline & MVsh & NEsh & NIsh & DTAsh & MVsh & NEsh & NIsh & DTAsh \\
\hline Mean & 10.99 & 12.38 & 0.78 & 3.65 & 10.96 & 10.69 & 0.64 & 3.56 \\
\hline Median & 8.09 & 9.05 & 0.31 & 0.99 & 8.09 & 9.05 & 0.31 & 0.99 \\
\hline Maximum & 75.11 & 94.20 & 26.98 & 42.37 & 62.07 & 66.10 & 6.42 & 32.93 \\
\hline Minimum & 0.32 & 0.00 & -2.14 & 0.00 & 0.72 & 0.00 & -1.30 & 0.00 \\
\hline Standard deviation & 9.85 & 25.93 & 2.22 & 6.26 & 9.66 & 12.29 & 1.18 & 5.74 \\
\hline
\end{tabular}

DTAsh = deferred tax assets per share of each bank; NIsh = net income per share; NEsh = value of net equity per share; MVsh = market value per share.

Source: Elaborated by the authors.

It is observed that the market value per share $(M V s h)$ of the banks in the Brazilian capital market is around $\mathrm{R} \$$ 10.00 , but with the large spread in the period it presents a high standard deviation, if it is considered that the period is 17 years (2000 to 2017), revealing relevant fluctuations in relation to the behavior of the market indicators of the banking entities. This same volatility is verified in relation to the independent variables of the model (NEsh, NIsh, and DTAsh), which are representative of the accounting data of the banks in the sample.

Table 4

Estimations of model 2 with cross-sectional fixed effects

\subsubsection{Estimations of the model}

The estimations of the Ohlson model (1995) are carried out using panel data with cross-sectional fixed effects, considering the results of the preliminary tests highlighted in the first part of section 4. It should be noted that, in this case, the number of observations was lower than in the MTB model, given the limited information in the Economatica ${ }^{\circledR}$ database. The results of the estimations are consolidated in Table 4.

\begin{tabular}{|c|c|c|}
\hline \multicolumn{3}{|c|}{$\begin{array}{c}\text { Model tested } \\
M V s h_{\mathrm{i}, \mathrm{t}}=\beta_{0}+\beta_{1}\left(N E s h_{i, t}-D T A s h_{\mathrm{i}, \mathrm{t}}\right)+\beta_{2} N I s h_{\mathrm{i}, \mathrm{t}}+\beta_{3} D T A s h_{\mathrm{i}, \mathrm{t}}+\varepsilon_{\mathrm{i}, \mathrm{t}}\end{array}$} \\
\hline Variable & Complete database & Winsorized database $(1 \%)$ \\
\hline C & $\begin{array}{c}12.6966 \\
(0.0000) \\
* * *\end{array}$ & $\begin{array}{l}12.3367 \\
(0.0000) \\
* * *\end{array}$ \\
\hline NEsh-DTAsh & $\begin{array}{l}0.03187 \\
(0.0092) \\
* * *\end{array}$ & $\begin{array}{c}0.0298 \\
\underset{* *}{(0.0383)}\end{array}$ \\
\hline NIsh & $\begin{array}{l}-0.4788 \\
(0.1451)\end{array}$ & $\begin{array}{l}-0.2628 \\
(0.3145)\end{array}$ \\
\hline DTAsh & $\begin{array}{l}-0.4709 \\
(0.0001) \\
* * *\end{array}$ & $\begin{array}{l}-0.4076 \\
(0.0000) \\
* * *\end{array}$ \\
\hline Period & $2000-2017$ & $2000-2017$ \\
\hline N. Obs. & 423 & 423 \\
\hline $\mathrm{R}^{2}$ & 0.4724 & 0.4781 \\
\hline $\mathrm{R}^{2}$ adjusted & 0.4461 & 0.4516 \\
\hline F statistic & 17.9970 & 18.0050 \\
\hline$F(p-$ value $)$ & 0.0000 & 0.0000 \\
\hline
\end{tabular}

DTAsh = deferred tax assets per share of each bank; NIsh = net income per share; NEsh-DTAsh = value of net equity per share, minus DTAs; MVsh = market value per share.

***, **, *: 1, 5, and 10\% level of significance, respectively. P-value in parentheses.

Source: Elaborated by the authors.

The results of the estimations reveal that, in both cases, the negative and statistically relevant relationship was found between the DTAs per share (DTAsh) and the dependent variable market value per share of the banks, corroborating the result presented in the previous model (1) and the arguments that support research hypothesis $\mathrm{H}_{1}$. Thus, it is revealed, through two different mechanisms for testing the relationships predicted in the hypotheses, 
that the relationship between the market value of the banks and DTAs is negative and relevant.

The confirmation by means of models with different theoretical formulations of the negative relationship and of the informational relevance of DTAs to the market value of the banks revealed in this investigation is important for confirming the risks and potential consequences for investors of the significant stock of
DTAs in Brazilian banks - a fact that is sensitive to the capital market.

The estimations also confirmed the expected positive relationship between the variables NEsh-DTAsh and the dependent variable $M V s h$, as stipulated by Ohlson (1995). For net income per share (NIsh), however, the positive relationship expected in theoretical terms was not confirmed.

\section{CONCLUSION}

Considering that the informational relevance for the capital market of deferred taxes (assets and liabilities) has been evaluated from various perspectives in the studies conducted by Ayers (1998), Amir et al. (2001), Chang et al. (2009), and Badenhorst and Ferreira (2016), but that these did not cover the banking industry, this study sought to investigate the informational relevance of DTAs in the Brazilian banking industry, evaluating whether relevance helps explain the market value of the book value of the banks. The aim, therefore, is to fill this gap, collaborating in the development of the literature on the topic, with a specific focus on the banking segment.

This is particularly important considering that the relevance of DTAs in Brazilian banking entities has caused international risk classification agencies to question the quality and resilience of the capital of these entities (Moody's Corporation, 2015; Standard \& Poor's Ratings Services, 2016).

The reasons and basis for investigating DTAs in this segment are highlighted by the potential implications they cause for banks and the market, as well as the way increasing asymmetries between accounting and tax measurements when calculating earnings affect the perception of investors and solidity of the banking institutions.

To test the hypothesis that the market evaluates the relevance of DTAs in the equity structure composition of the banks in a negative way, reducing the market value of the book value of these entities, estimations of two models, MTB and the Ohlson (1995), were carried out using data for publicly-held banks from the period covering March of 2000 to June of 2017. To ensure the robustness of the findings, complete and winsorized databases were used, and in the MTB model two ways of measuring the relative importance of the DTA stock were used - as a proportion of the banks' total assets and of their NE.

The results of the empirical tests confirmed the expectations of the research hypothesis, revealing that DTAs have informational relevance for the capital market, and their relevance in the equity structure is negatively associated with the market value of the book value of the banks operating in the country. These results were corroborated in the set of combinations of estimations of the two models, with treatment and without treatment of outliers and independently of the way of measuring the relevance of the DTA stock.

This evidence confirms the hypothesis that the Brazilian capital market negatively prices the relevance of the DTA stock in the equity structure of publiclyheld banks, which can be explained (i) by the sterility of these assets; (ii) by questions regarding the capacity to generate future economic benefits of DTAs and effective control by the entity; (iii) by the potential reduction in the informational quality of financial statements, since measuring these assets by their nominal value would go against the economic essence of future cash flow predictions, as an appropriate representation of the value of assets in time; and (vi) by the subjective and questionable assumptions that support the recognition of DTAs, including the presumption of future taxable income.

As the main contributions to the development of the literature, besides seeking to fill the gap involving the incipience of studies, even in the international literature, about the effects of DTAs on the banking industry, the study offers empirical evidence regarding how the market evaluates assets originating from the asymmetries between the taxable and corporate earnings of banks that give origin to DTAs. This is particularly relevant if we consider how possible signs of weakness of the capital and income of banking entities can negatively affect the perception of depositors, with the potential negative consequences for the functioning of the banking system, given the characteristics of this segment, in which confidence in the solidity of the institutions is a basic premise for their adequate functioning.

The result of the research also contributes to highlighting that these asymmetries should be reduced, signaling to the regulatory authorities of the financial 
and taxation system that a solution should be found. Banking entities, due to the nature of their activities, are in constant evolution with regard to the recognition and measurement of risks, with an impact on accruals, which are fundamental for ensuring the system's solidity. Yet, while these expenses (adjustments to risks) are not considered at the same time - or at least the asymmetries mitigated - by the tax system, the banking industry will tend to continue with the negative weight that this asymmetry causes in the equity structure of banks. That is, the benefits of recognizing expected losses derived from the management of the institutions' risks are reduced by the negative perception of the constitution of the DTAs associated with the recording of these losses.
As a main limitation, note that this study focused on the perception of investors and, because it uses this perspective, it was limited to publicly-held banks, which partially represent the financial conglomerates operating in the Brazilian banking system. It therefore does not contemplate many of the Brazilian banking institutions whose equity structure involves closed capital.

As a suggestion for future studies, it is important to develop research covering more of the system, also including privately-held banks, from the perspective of the functioning of the banking market per se. In this case, the evaluation could be of the impact of DTAs on the cost of credit and on the valuation of the other assets and liabilities of banking institutions.

\section{REFERENCES}

Akhigbe, A., Madura, J., \& Marciniak, M. (2012). Bank capital and exposure to the financial crisis. Journal of Economics and Business, 64(5), 377-392.

Amir, E., Kirschenheiter, M., \& Willard, K. (2001). The aggregation and valuation of deferred taxes. Review of Accounting Studies, 6(2-3), 275-297. https://doi. org/10.1023/A:1011619010143

Ayers, B. C. (1998). Deferred tax accounting under SFAS No. 109: An empirical investigation of its incremental value-relevance relative to APB No. 11. Accounting Review, 73(2), 195-212. https://doi.org/10.2308/jata.2008.30.2.107

Badenhorst, W. M., \& Ferreira, P. H. (2016). The financial crisis and the value relevance of recognised deferred tax assets. Australian Accounting Review, 26(3), 291-300.

Basel Committee on Banking Supervision. (2011). Basel III: A global regulatory framework for more resilient banks and banking systems - revised version. Retrieved from https:// www.bis.org/publ/bcbs189.htm.

Beaver, W. H. (1998). Financial reporting: An accounting revolution (3a ed.). Upper Saddle River, NJ: Prentice Hall International.

Beechy, T. H. (2007). The make believe world of future income taxes/L'univers fictif des impôts futurs. Accounting Perspectives, 6(3), 221-229. https://doi.org/10.1506/ap.6.3.1

Black, H. A. (1966). Excerpts from accounting research study No. 9: Interperiod allocation of corporate income taxes. Journal of Accountancy (pre-1986), 122(1), 41-47.

Berk, J. B. (1997). Does size really matter? Financial Analysts Journal, 53(5), 12-18.

Brown, G. A., Collins, R., \& Thornton, D. B. (1993). Professional judgment and accounting standards. Accounting, Organizations and Society, 18(4), 275-289. https://doi. org/10.1016/0361-3682(93)90017-Z

Cao, Z., \& Narayanamoorthy, G. (2006). Accounting and litigation risk. Retrieved from https://corpgov.law.harvard. edu/2012/11/26/accounting-and-litigation-risk/

Carey, J. L. (1944). What are corporate income taxes? Journal of Accountancy (pre-1986), 77(6), 425-426.
Chang, C., Herbohn, K., \& Tutticci, I. (2009). Market's perception of deferred tax accruals. Accounting \& Finance, 49(4), 645673. https://doi.org/10.1111/j.1467-629X.2009.00307.x

Collins, D. W., Maydew, E. L., \& Weiss, I. S. (1997). Changes in the value-relevance of earnings and book values over the past forty years. Journal of Accounting and Economics, 24(1), 39-67. https://doi.org/10.1016/S0165-4101(97)00015-3

Comitê de Pronunciamentos Contábeis. (2009). Pronunciamento Técnico CPC 32: Tributos sobre o lucro. Correlação às normas internacionais de contabilidade - IAS. Retrieved from http://static.cpc.aatb.com.br/Documentos/340 CPC_32_rev\%2003.pdf.

Conselho Monetário Nacional. (2002). Resolução No 3.059, de 20 de dezembro de 2002. Dispõe sobre registro contábil de créditos tributários das instituições financeiras e demais instituições autorizadas a funcionar pelo Banco Central do Brasil. Retrieved from https://www.bcb.gov.br/pre/ normativos/res/2002/pdf/res_3059_v3_l.pdf.

Dantas, J. A., Medeiros, O. R. D., \& Lustosa, P. R. B. (2006). Reação do mercado à alavancagem operacional: um estudo empírico no Brasil. Revista Contabilidade \& Finanças, 17(41), 72-86.

Dantas, J. A., Galdi, F. C., Capelletto, L. R., \& Medeiros, O. R. (2013). Discricionariedade na mensuração de derivativos como mecanismo de gerenciamento de resultados em bancos. Revista Brasileira de Finanças, 11(1), 17-48.

Edvinsson, L., \& Malone, M. S. (1997). Intellectual capital: Realizing your companyl's true value by finding its hidden brainpower. New York, NY: HarperCollins.

Fama, E. F., \& French, K. R. (1995). Size and book-to-market factors in earnings and returns. The Journal of Finance, 50(1), 131-155. https://doi.org/10.1111/j.1540-6261.1995.tb05169.x

Fama, E. F., \& French, K. R. (1992). The cross-section of expected stock returns. The Journal of Finance, 47(2), 427-465. https:// doi.org/10.1111/j.1540-6261.1992.tb04398.x

Financial Accounting Standards Board. (1992). Statement of Financial Accounting Standards No. 109. Accounting for 
Income Taxes. Retrieved from https://www.fasb.org/summary/ stsum109.shtml.

Graul, P. R., \& Lemke, K. W. (1976). On the economic substance of deferred taxes. Abacus, 12(1), 14-31. https://doi. org/10.1111/j.1467-6281.1976.tb00284.x

Hanlon, M. (2005). The persistence and pricing of earnings, accruals, and cash flows when firms have large book-tax differences. The Accounting Review, 80(1), 137-166. https:// doi.org/10.2308/accr.2005.80.1.137

Hanlon, M., \& Heitzman, S. (2010). A review of tax research. Journal of Accounting and Economics, 50(2), 127-178. https://doi.org/10.1016/j.jacceco.2010.09.002

Hastings J., C., Mosteller, F., Tukey, J. W., \& Winsor, C. P. (1947). Low moments for small samples: a comparative study of order statistics. The Annals of Mathematical Statistics, 18(3), 413-426.

Hausman, J. A. (1978). Specification tests in econometrics. Econometrica: Journal of the Econometric Society, 46(6), 1251-1271. https://doi.org/10.2307/1913827

Healy, P. M. \& Palepu, K. G. (2012). Business analysis valuation: Using financial statements (4a ed.). Connecticut (CT): Cengage Learning.

Herring, H., Jacobs, F., Davidson, S., \& Skelton, L. (1977). Controversy over expected behavior of deferred tax credits. Journal of Accountancy, 143(4), 53-59.

International Accounting Standards Board. (2001). IAS 12 Income Taxes. Retrieved from https://www.iasplus.com/en/ standards/ias/ias12.

Jensen, M. C., \& Meckling, W. H. (1976). Theory of the firm: Managerial behavior, agency costs and ownership structure. Journal of Financial Economics, 3(4), 305-360. https://doi.org/10.1016/0304-405X(76)90026-X

Kam, V. (1990). Accounting theory. New York, (NY): Wiley.

Kronbauer, C. A., Souza, M. A., Alves, T. W., \& Rojas, J. M. (2010). Fatores determinantes do reconhecimento de ativos fiscais diferidos. Revista Universo Contábil, 6(4), 68-88.

Kronbauer, C. A., Souza, M. A., Lima Webber, F., \& Ott, E. (2012). Impacto do reconhecimento de ativos fiscais diferidos na estrutura financeira e no desempenho econômico de empresas brasileiras. Revista Contemporânea de Contabilidade, 9(17), 39-60.

Moody's Corporation (2015). Impact of DTA conversion laws on Moody's rated banks, Italy, Spain, Portugal, Brazil, Greece.

Moura, E., \& Martinez, A. L. (2006). Ativos fiscais diferidos nas instituições financeiras: uma abordagem sobre riscos. Contabilidade Vista \& Revista, 17(2), 11-30.

Nurnberg, H. (1971). Cash movements analysis of the accounting for corporate income taxes. East Lansing (MI): Division of
Research, Graduate School of Business Administration, Michigan State University.

Ohlson, J. A. (1995). Earnings, book values, and dividends in equity valuation. Contemporary Accounting Research, 11(2), 661-687. https://doi.org/10.1111/j.1911-3846.1995. tb00461.x

Oliveira, V. A., Lemes, S., \& Almeida, L. C. F. (2008). Gerenciamento de resultados contábeis por meio de ativos fiscais diferidos. Contabilidade, Gestão e Governança, 11(1-2), 153-169.

Revsine, L. (1969). Some controversy concerning "controversial accounting changes". The Accounting Review, 44(2), 354-358.

Roos, J., Edvinsson, L., \& Dragonetti, N. C. (1997). Intellectual capital: Navigating the new business landscape. New York (NY): Springer.

Schuh, C., Ribeiro, S. P., Simon, D. S., \& Kronbauer, C. A. (2018). Fatores influenciadores do reconhecimento de ativos fiscais diferidos em empresas do Ibovespa. Revista Universo Contábil, 14(1), 29-49.

Schultz, S. M., \& Johnson, R. T. (1998). Income tax allocation: the continuing controversy in historical perspective. The Accounting Historians Journal, 25(2), 81-111. https://doi. org/10.2308/0148-4184.25.2.81

Shield, H. J. (1957). Allocation of income-taxes. Journal of Accountancy, 103(4), 53-60.

Silva, A. O., \& Dantas, J. A. (2015). Impacto da política de dividendos no valor de mercado das instituições financeiras no Brasil. Revista de Gestão, Finanças e Contabilidade, 5(4), 43-63.

Skinner, D. J. (2008). The rise of deferred tax assets in Japan: The role of deferred tax accounting in the Japanese banking crisis. Journal of Accounting and Economics, 46(2), 218-239. https:// doi.org/10.1016/j.jacceco.2008.07.003

Skinner, R. M., \& Milburn, J. A. (2001). Accounting standards in evolution ( $2 \mathrm{a}$ ed.). Toronto: Prentice-Hall.

Standard \& Poor's Ratings Services. (2016). Relatório: Bancos brasileiros enfrentam um longo e difícil ciclo de desalavancagem, enquanto aumentam os empréstimos problemáticos. New York (NY): McGraw Hill Financial.

Van Breda, M. F., \& Ferris, K. R. (1989). Accounting for deferred income taxes: Understanding the new approach. Journal of Managerial Issues, 1(1), 76-85.

Watts, R. L., \& Zimmerman, J. L. (1986). Positive accounting theory. Englewood Cliffs (NJ): Prentice-Hall.

Wolk, H. I., Dodd, J. L., \& Rozycki, J. J. (2008). Accounting theory: conceptual issues in a political and economic environment (Vol. 2). Thousand Oaks (CA): Sage. 